\title{
First detection of Rio Negro virus (Venezuelan equine encephalitis complex subtype VI) in Córdoba, Argentina
}

\author{
María Belén Pisano ${ }^{1 /+}$, Lorena Ivana Spinsanti ${ }^{1}$, Luis Adrián Díaz ${ }^{1}$, Adrián Alejandro Farías ${ }^{1}$, \\ Walter Ricardo Almirón², Viviana Elizabeth Ré1, Marta Silvia Contigiani \\ 1'Instituto de Virología Dr JM Vanella, Facultad de Ciencias Médicas ${ }^{2}$ Centro de Investigaciones Entomológicas de Córdoba, \\ Facultad de Ciencias Exactas, Universidad Nacional de Córdoba, Enfermera Gordillo Gómez s/n, 5016 Córdoba, Argentina
}

\begin{abstract}
Rio Negro virus (RNV) (Venezuelan equine encephalitis subtype VI) circulates only in Argentina; in northern provinces, isolates have been obtained from mosquitoes and rodents since 1980 and have been associated with acute febrile illness in humans. However, no studies of RNV have been performed in the central area of the country. We carried out molecular and serological detection of RNV in Córdoba, a province of the central part of the country, in mosquitoes and humans, respectively. One mosquito pool tested positive for alphavirus RNA by reverse transcriptase-nested polymerase chain reaction (RT-nested PCR). Subsequent sequencing determined that this alphavirus grouped with $R N V$. Serological studies detected antibodies to RNV in one human serum sample, which was obtained during the same period that $R N V$ was detected using the aforementioned molecular methods. This is the first report of RNV circulation in the central area of Argentina, indicating an expansion of its original distribution. These results highlight the importance of strengthening surveillance procedures in endemic areas, as well as in new regions where RNV may emerge.
\end{abstract}

Key words: Rio Negro virus - Venezuelan equine encephalitis - Argentina

Rio Negro virus (RNV) belongs to the enzootic group of Venezuelan equine encephalitis (VEE) complex (Alphavirus, Togaviridae) and corresponds to the subtype VI of its serological classification (Weaver et al. 2004). The viral genome consists of a single-stranded positivesense RNA of 11.5 kilobases (Brault et al. 2004). The structural proteins (E1, E2 and C) are encoded in the 3 ' third of the genome and nonstructural proteins (nsPs 1-4) are encoded in the remaining 5' two thirds (Griffin 2001). Enzootic VEE subtypes are equine avirulent; however, some may be pathogenic to humans, which are end hosts, and in some cases these infections may be fatal (Johnson \& Martin 1974). Most human infections are mild or asymptomatic, producing symptoms similar to those of dengue or influenza (headache, chills, fever, myalgias, retroocular pain, nausea and vomiting), which last three-five days (PAHO 2011).

RNV circulates only in Argentina and was isolated for the first time in 1980 from Culex (Melanoconion) delpontei mosquitoes in the province of Chaco, a subtropical area in the northern part of the country. In that study, 19 isolates of this virus were obtained and subsequently classified as a new enzootic subtype in the VEE complex (Mitchell et al. 1985). In 1989, RNV produced an outbreak of acute febrile illness in humans of General Belgrano Island (province of Formosa, subtropical area). This out-

Financial support: FONCYT (38060), CONICET-PIP, SECYT-UNC + Corresponding author: pisanomb@yahoo.com

Received 31 May 2011

Accepted 8 November 2011 break was originally attributed to dengue virus due to the similarity of the symptoms (Contigiani et al. 1993). Two years later, a strain of this virus (denoted as F89) was isolated from rodents captured in the same province (Contigiani et al. 1999). Additionally, serological studies have demonstrated the presence of antibodies against subtypes VI and I (strain TC83) in inhabitants of General Belgrano Island (Cámara et al. 2003). Recent investigations have detected RNV in mosquitoes from Chaco (Pisano et al. $2010 \mathrm{~b}$ ) and, for the first time, in mosquitoes from the province of Tucumán, demonstrating a wider distribution in the northern areas of Argentina (Pisano et al. 2010a) than previously suspected. In these provinces, Pixuna virus (PIXV), another enzootic member of the VEE complex (subtype IV), has also been detected, sometimes circulating within the same region and at the same time as RNV (Pisano et al. 2010a). These studies have demonstrated the presence of more than one enzootic VEE subtype in subtropical regions of Argentina.

The aim of this study was to investigate the circulation of RNV in central temperate areas of Argentina. We analysed the presence of this virus in Córdoba during 2004 and 2005. Mosquitoes were tested by molecular detection and humans by serological tests.

\section{SUBJECTS, MATERIALS AND METHODS}

Molecular detection in mosquitoes - Mosquitoes were collected from January-May 2004 and from JanuaryMarch 2005 with CDC light traps supplemented with $\mathrm{CO}_{2}$ using dry ice in the city of Córdoba ( $31^{\circ} 24^{\prime} 03^{\prime}$ 'S $\left.64^{\circ} 10^{\prime} 54^{\prime} \mathrm{W}\right)$, located in the central area of Argentina (Fig. 1, Table I). The mosquitoes were transported to the laboratory alive under cold conditions and unengorged females were pooled into groups of up to 50 according to species, study site and date of collection. They were then 
stored at $-70^{\circ} \mathrm{C}$ until processing. Each pool was triturated in a mortar with sterile minimum essential medium (Gibco, Invitrogen, NY, USA) supplemented with $10 \%$ fetal bovine serum and $1 \%$ gentamicin and afterwards centrifuged at 11,400 $\mathrm{g}$ for $30 \mathrm{~min}$. Supernatants were stored at $-70^{\circ} \mathrm{C}$ until molecular detection was performed.

Viral RNA was extracted using Trizol Reagent (Invitrogen BRL, Life Technologies, Rockville, MD, USA) according to the manufacturer's instructions. Reverse transcriptase-nested polymerase chain reaction (RTnested PCR) for alphavirus detection was performed, amplifying a 195-bp fragment that corresponded to the nsP4 region, as described by Sánchez Seco et al. (2001). PCR products of the expected size were purified using QIAquick Gel Extraction Kit (Qiagen, Valencia, CA, USA) and sequenced in both directions by an ABI automatic sequencer. Nucleotide sequences were analysed by BLAST 2.2.19 (blast.ncbi.nlm.nih.gov) (Zhang et al. 2000) to determine the identity of amplicons. A dendrogram was constructed with the program MEGA version 4.0 software (Center for Evolutionary Functional Genomics, Arizona, USA) using the neighbour joining method and p-distance parameter (Tamura et al. 2007).

Detection of antibodies in humans - Serum samples from humans between the ages of zero- 80 years were screened for antibodies to RNV using the neutralization test (NT) (Early et al. 1967). Positive samples were also tested against PIXV to discard cross reactions. NTs were performed using African green monkey kidney (Vero) cells. Samples were collected in Córdoba (in Health Centres from municipality of Córdoba) between November 2004-April 2005, during an outbreak of St. Louis encephalitis virus (Spinsanti et al. 2008). All samples were initially tested at a dilution of 1:10 and positive samples were further titrated to determine the end-point titter. This study was designed as a non-associated anonymous survey; the only data registered were the number of the sample, the date of sampling and the subject's age (years) and address (street and neighbourhood).

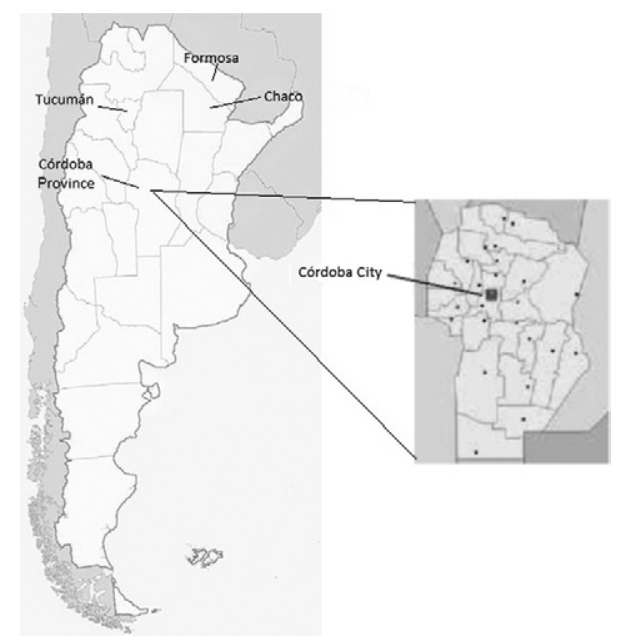

Fig. 1: map showing location of the city of Córdoba, in the province of Córdoba, Argentina.

\section{RESULTS AND DISCUSSION}

Sixty-two mosquito pools (1,524 individuals) belonging to eight species were collected. The most abundant species were Culex (Culex) interfor (48.8\%), Culex quinquefasciatus (27.8\%) and Aedes albifasciatus (6.6\%). All mosquito pools were tested for alphavirus RNA by RT-nested PCR and one pool of $C x$. interfor was positive (denoted as ArgCba448). The mosquitoes that comprised this pool were collected in February 2005 in the southern part of the city.

Culex (Melanoconion) delpontei was originally postulated as the main vector of RNV in 1980 for the region of Chaco because 12 strains of the virus were isolated from this species (Mitchell et al. 1985). Recent studies have demonstrated the presence of RNV in several other mosquito species in Chaco and Tucumán (Pisano et al. 2010a, b). In those investigations, there were few (Chaco) or no (Tucumán) pools of $C x$. delpontei collected, suggesting changes in the ecoepidemiological pattern of RNV in those regions over time. In Córdoba, this was the first detection of RNV and Cx. delpontei is not listed for this province (Mitchell \& Darsie 1985). These data, along with all that have been previously mentioned, could indicate that RNV is being transmitted by other mosquito genera or species throughout Argentina.

The positive sample ArgCba448 was sequenced and distance analysis showed that it clustered with RNV within the VEE complex (Fig. 2). We also included previous RNV isolates from the Argentinean provinces of Formosa, Chaco and Tucumán in this analysis. It was not possible to carry out detailed phylogenetic analysis due to the short length of the amplicon. Sequencing of more variable regions of the viral genome (E1, E2) would be necessary to perform a larger phylogenetic analysis to obtain more information about RNV variability and routes of dispersion in Argentina.

Detection of human antibodies against RNV was performed in 409 serum samples. One sample (0.24\%) from March 2005 tested positive for antibodies to RNV and negative for antibodies to PIXV. It corresponded to a resident of the south part of Córdoba. The titre was 320 , which could indicate circulation in this period, although a better estimation of recent infection would be based on $\operatorname{IgM}$ detection.

Our results show that RNV circulated in the city of Córdoba during 2005. This is the first report of its detection in this temperate province. Molecular results show a strong correlation with serology, demonstrating that the circulation in mosquitoes occurred during the same period in which the human infection took place. This finding indicates expansion of RNV into new regions, probably due to climate changes and the increase of commercial activities in that area, especially in northern regions of the country. Further studies are needed to investigate whether RNV and other members of the VEE complex are actually circulating in the city of Córdoba or could have circulated in 2005 without becoming established in the region.

These results highlight the need for constant clinical and virological surveillance in Córdoba. The occurrence of clinical cases of febrile undifferentiated illness 


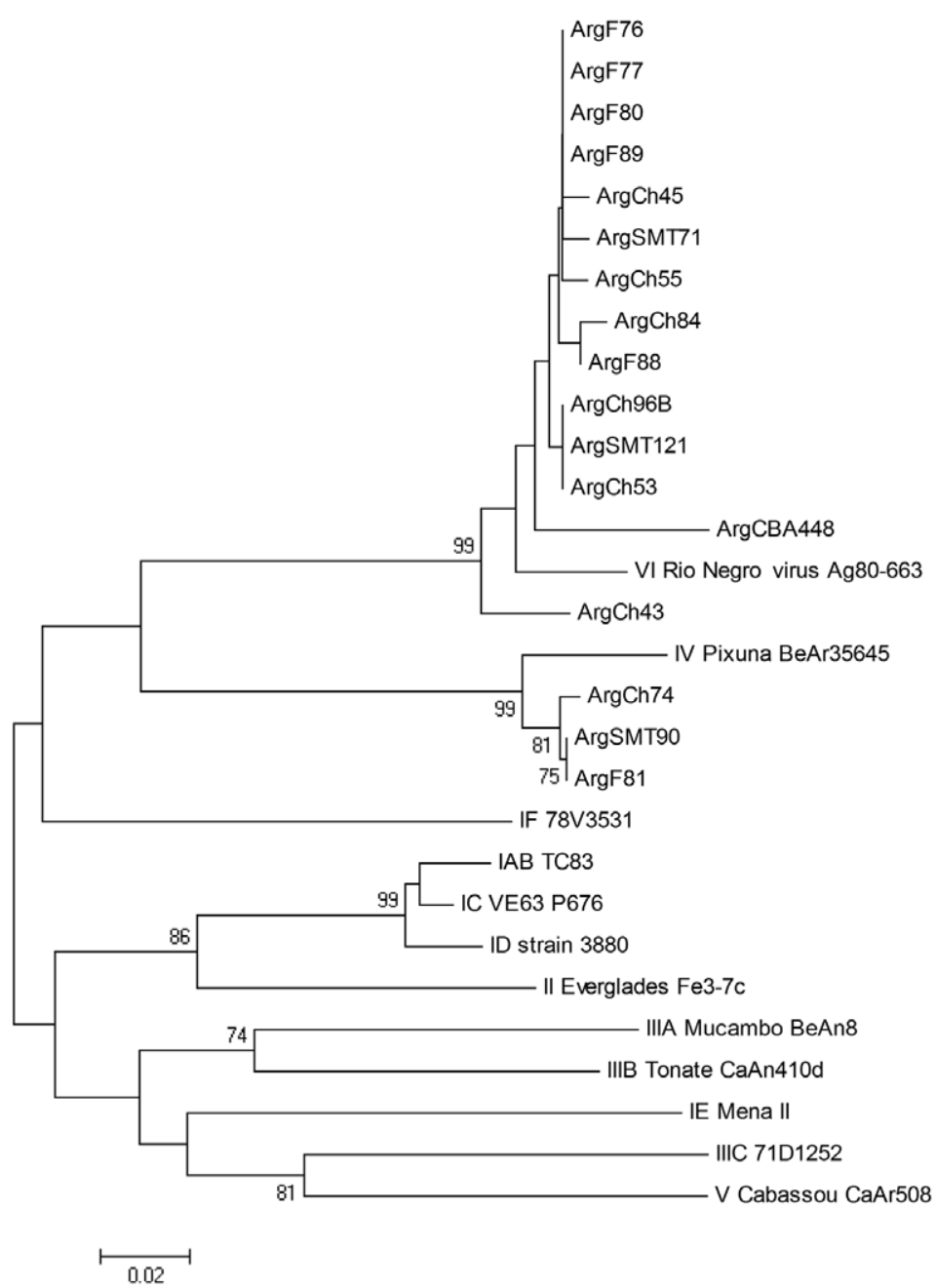

Fig. 2: dendogram constructed with Neighbour joining method and p-distance parameter included positive sample ArgCba448, prototype Venezuelan equine encephalitis complex viruses and previous Argentinean isolates, indicated by $\mathrm{ArgCh}$ (isolates from the province of $\mathrm{Chaco}$ ), $\mathrm{ArgF}$ (isolates from the province of Formosa) and ArgSMT (isolates from the province of Tucumán) (GenBank accessions EU649784, EU658924, EU658925, EU848531, EU848532, EU848534, EU848536, FJ002856, FJ002857, GQ885141, GU002046, HM804026 and HM991260). The number of replicate trees in which the associated taxa clustered together in the bootstrap test (1,000 replicates) is shown next to the branches.

\section{TABLE}

Species, number of specimens, number of pools analyzed by reverse transcriptase-nested polymerase chain reaction for alphavirus detection and number of positive pools in the studied periods (2004 and 2005)

\begin{tabular}{lccc}
\hline Species & $\begin{array}{c}\text { Specimens } \\
\text { collected } \\
\text { (n) }\end{array}$ & $\begin{array}{c}\text { Pools } \\
\text { analyzed } \\
\text { (n) }\end{array}$ & $\begin{array}{c}\text { Positive } \\
\text { pools } \\
\text { (n) }\end{array}$ \\
\hline Aedes aegypti & 9 & 3 & 0 \\
Aedes albifasciatus & 100 & 8 & 0 \\
Aedes scapularis & 99 & 5 & 0 \\
Culex interfor & 744 & 22 & 1 \\
Culex quinquefasciatus & 423 & 15 & 0 \\
Culex saltanensis & 82 & 5 & 0 \\
Culex spp & 26 & 2 & 0 \\
Mansonia titillans & 41 & 2 & 0 \\
\hline
\end{tabular}

produced by RNV must be taken into account for differential etiologic diagnosis with other arboviruses that circulate in the same region, especially in cases reported as probable dengue. Studies of longer and more variable genomic regions are also important for a better understanding of this virus and its impact on public health.

\section{ACKNOWLEDGEMENTS}

To the Centro Periférico de Salud 58 and Medicina Preventiva, Córdoba, for helping us to collect serum samples, and to Javier Aguilar, Brenda Konigheim, María Elisa Rivarola and Laura Tauro, for their technical assistance in cell culture.

\section{REFERENCES}

Brault AC, Powers AM, Ortíz D, Estrada Franco JG, Navarro López R, Weaver SC 2004. Venezuelan equine encephalitis emergence: enhanced vector infection from a single aminoacid substitution in the envelope glycoprotein. PNAS 101: 11344-11349.

Cámara A, Diaz G, Vega V, Basualdo M, Contigiani M 2003. Seroprevalence of antibodies to Venezuelan equine encephalitis 
complex (subtype IAB and VI) in humans from General Belgrano Island, Formosa, Argentina. Rev Inst Med Trop S Paulo 45: 201-204.

Contigiani M, Cámara A, Spinsanti L, Díaz G 1999. Caracterización bioquímica y biológica de cepas del virus del complejo encefalitis equina Venezolana (familia Togaviridae). An Fund A Roemmers 12: 119-123.

Contigiani MS, Basualdo M, Cámara A, Ramírez A, Díaz G, González D, Medeot S, Osuna D 1993. Presencia de anticuerpos contra virus de la encefalitis equina Venezolana subtipo VI en pacientes con enfermedad febril aguda. Rev Arg Microbiol 25: 244-251.

Early E, Peralta PH, Johnson KM 1967. A plaque neutralization method for arboviruses. Proc Soc Exp Biol Med 25: 741-747.

Griffin DE 2001. Alphaviruses. In D Knipe, Fields virology, Lippincott, Williams and Wilkins, Philadelphia, p. 917-962.

Johnson KM, Martin DH 1974. Venezuelan equine encephalitis. Adv Vet Csi Comp Med 18: 79-116.

Mitchell CJ, Darsie RF Jr 1985. Mosquitoes of Argentina. Part II. Geographic distribution and bibliography (Diptera: Culicidae). Mosq Syst 17: 279-360.

Mitchell CJ, Monath TP, Sabattini MS, Cropp C, Daffner J, Calisher C, Christensen H 1985. Arbovirus investigations in Argentina II. Arthropod collections and virus isolations from Argentine mosquitoes, 1977-1980. Am J Trop Med Hyg 34: 945-955.

PAHO - Pan American Health Organization 2011. Epidemiological alert. Arthropod-borne equine encephalitis. Available from: new. paho.org/hq/index.php?option=com_content\&task=view\&id=12 39\&Itemid $=1091 \&$ lang $=$ es.

Pisano MB, Dantur MJ, Ré V, Díaz LA, Farías A, Sánchez Seco MP, Tenorio A, Almirón WR, Contigiani MS 2010a. Cocirculation of Rio Negro virus (RNV) and Pixuna virus (PIXV) in Tucumán province, Argentina. Trop Med Int Health 15: 865-868.

Pisano MB, Ré V, Díaz LA, Farías A, Stein M, Sánchez Seco MP, Tenorio A, Almirón WR, Contigiani MS 2010b. Enzootic activity of Pixuna and Rio Negro viruses (Venezuelan equine encephalitis complex) in a neotropical region of Argentina. Vec Borne Zoon Dis 10: 199-201.

Sánchez Seco MP, Rosario D, Quiroz E, Guzmán G, Tenorio A 2001. A generic nested-RT-PCR followed by sequencing for detection and identification of members of the alphavirus genus. $J$ Virol Meth 95: 153-161.

Spinsanti LI, Díaz LA, Glatstein N, Arselán S, Morales MA, Farías AA, Fabbri C, Aguilar JJ, Ré V, Frías M, Almirón WR, Hunsperger E, Siirin M, Travassos Da Rosa A, Tesh RB, Enría D, Contigiani MS 2008. Human outbreak of St. Louis encephalitis detected in Argentina, 2005. J Clin Virol 42: 27-33.

Tamura K, Dudley J, Nei M, Kumar S 2007. Molecular Evolutionary Genetics Analysis (MEGA) software version 4.0. Mol Biol Evol 24: 1596-1599.

Weaver SC, Ferro C, Barrera R, Boshell J, Navarro JC 2004. Venezuelan equine encephalitis. Annu Rev Entomol 49: 141-174.

Zhang Z, Schwarts S, Wagner L, Miller W 2000. A greedy algorithm for aligning DNA sequences. J Comput Biol 7: 203-214. 